\title{
Comparative studies on nutritional quality of commercial wheat flour in Bangladesh
}

\author{
A. Saeid ${ }^{1}$, S. Hoque ${ }^{1}$, U. Kumar ${ }^{1}$, M. Das ${ }^{1}$, N. Muhammad ${ }^{2}$, M. M. Rahman ${ }^{3}$ and M. Ahmed $^{1 *}$ \\ ${ }^{l}$ Department of Food Processing and Preservation Hajee Mohammad Danesh Science and Technology University, Dinajpur. \\ ${ }^{2}$ Department of Agricultural Extension Hajee Mohammad Danesh Science and Technology University, Dinajpur. \\ ${ }^{3}$ Senior Scientific Officer, Institute of Food Science and Technology (IFST), Bangladesh Council of Scientific and Industrial \\ Research (BCSIR), Dhaka-1205, Bangladesh.
}

\begin{abstract}
Cereal industry and its derived products have a large economic and social importance worldwide. Baking industries are extensively using wheat flour to produce various baked products. Therefore, in this investigation it is intended to study and determine proximate, physicochemical, functional properties of six brand of wheat flour in Bangladesh. The entire brand had moisture contents: 9.90-12.48\%, protein: $8.67-12.47 \%$, fat: $0.893-1.387 \%$ and ash content: $0.387-0.707 \%$. The ACI brand had the highest amount of protein of $12.47 \%$ whereas Romoni brand had highest fat of $1.387 \%$, fiber: $0.26 \%$, gluten content: $15.34 \%$ and water absorption index of $1.9 \mathrm{~g} / \mathrm{g}$ as compared to other brands. In addition, sodium and calcium content were higher in ACI brand whereas potassium content was higher in Romoni brand. Results showed that wheat flour from all brand could be used to make various type of baked products.
\end{abstract}

Keywords: Wheat flour; Proximate analysis; Physiochemical properties and Functional properties

\section{Introduction}

Wheat (Triticum aestivum L.) is the most widely produced cereal and one of the most important staple food crops in the world (Tama's et al., 2009). The global wheat production was 699.4 million metric tons estimated in the year of 2011-2012 (FAO, 2012). In Bangladesh it was cultivated in 358032 hectors of land and the production was 995356 metric tons in 2011-2012 (BBS, 2012). Although, wheat is less important than rice but now it is recognized as the second cereal crop in Bangladesh (Hasan et al., 2008) and 9\% of the daily caloric intake is received from wheat (Tama's et al., 2009). Wheat is a rich source of carbohydrate. It also contain protein, fat, ash, fiber, and vitamins as well as mineral such as sodium, potassium, calcium, magnesium, iron, phosphorus, copper, zinc and manganese ( Kumar et al., 2011).

Usually, wheat flour is produced by milling whole wheat kernel. Wheat flour has distinguished characteristics from other cereals due to its unique dough forming properties (Wrigley, 2004). The quality of wheat flours can be measured by several parameters including protein, moisture, gluten; and by sedimentation, enzyme activity and rheological properties (Hruskova and Famera, 2003). It is important to note that the quality of gluten is not only measured by the quantity of protein but also measured by the degree of extensibility and elasticity of dough (Duska et al., 2001). Higher protein content (10-14.5\%) indicate the harder and stronger the flour and lower protein content (6-10\%) indicate the softer the flour. High protein flour is used to produce crusty and chewy breads and low protein flour is used to produce bakery product such as cake, biscuit, puffins and pie crusts etc (Chowdhury et al., 2012). It has been commonly accepted that increase in total protein content of the flour is due to increase in gluten content (Perten et al., 1992).

Moisture content is one of the important factors to determine the quality of flour and it's shelf life. Normal moisture content range in wheat flour is $11-14 \%$ (Syeda et al., 2012). If moisture content rises above normal range flour is susceptible to fungi and mold growth as a result of increased enzyme activity, insect infestation and flavor change. Higher lipolysis and proteolytic enzyme activities are related to

\footnotetext{
*Corresponding author: E-mail: anandhstu@yahoo.com
} 
higher moisture content which further lead to loss in nutrients mainly protein and fat (Hoseney, 1994).

The ash content is a measure of total amount of mineral present in wheat flour. Ash content indicates milling performance that indirectly showing the amount of bran contamination in flour. Mineral content also depend on various factors such as soil, climate, variety and cultural practices. Amount of ash in flour can affect color which imparting a darker color to finished products. Some specialty products requiring particularly white flour call for low ash content while whole wheat flour have high ash content.

Normally, wheat flour is used to prepare biscuit, cake, puffins, toast, bread, baby formulates, noodles, confectionary, breakfast and soup making (Kumar et al., 2011). Besides that, the wheat is also used for production of alcoholic and other drinks, as well as cattle food production (Husejin et al., 2009).

Usually quality of finished product is depended on the quality of raw ingredients. So, the study of original quality of market flour in terms of nutrients properties such as protein, fat, mineral and so on have to be informed to people, government and companies. This information will help the people to buy good quality flour and also will increase the consciousness of government, companies and people. The purpose of this study was to investigate the various quality parameter of commercial wheat flour in Bangladesh those included proximate composition, crude fiber, mineral contents, amylose and starch and determination of some functional properties.

\section{Materials and methods}

\section{Proximate composition of wheat flour}

Moisture, crude protein, fat and ash content of flours were determined by official methods (AOAC, 2000) and the gluten content was determined according to the method reported by Taneya et al. (2014).

\section{Determination of crude fibre}

The fiber content was determined according to the method reported by Ayesha et al. (2002) with some modification. Fat free $(2 \mathrm{gm})$ sample was taken in a $500 \mathrm{ml}$ beaker and added $200 \mathrm{ml} 0.255 \mathrm{~N} \mathrm{H}_{2} \mathrm{SO}_{4}$ boiled for $30 \mathrm{~min}$. constant volume was mentioned by addition of distilled water at frequent interval. After that the mixture was filtered with muslin filter cloth and the residue was washed with hot water until completely free from acid. Then residue was transferred into beaker and $200 \mathrm{ml}$ of $0.313 \mathrm{~N} \mathrm{NaOH}$ was added and boiled 30 min. And then after that 30 minutes the mixture was filtered through muslin cloth and residue was washed with hot water till alkali free and then washing with alcohol and diethyl ether. Then it was transferred into crucible and dried at $105^{\circ} \mathrm{C}$ for overnight. Then crucible was heated in a muffle furnace at $600^{\circ} \mathrm{C}$ for $3-5 \mathrm{hrs}$ after that cooled and weighed. The crude fiber was obtained by the following formula:

$$
\text { \% Crude fiber }=\frac{w_{1}-w_{2}}{w} \times 100
$$

Here,

$\mathrm{w}_{1}=$ weight of crucible with ashed sample

$\mathrm{w}_{2}=$ weight of the crucible

$\mathrm{w}=$ weight of sample

\section{Determination of mineral}

The Mineral content was determined according to the method reported by Said Wahab (2010) with some modification. Wheat flour (1g) was taken in $50 \mathrm{ml}$ flasks and $10 \mathrm{ml}$ of conc. Nitric acid and $5 \mathrm{ml}$ of conc. perchloric acid was added to the flask and digested using a hot plate until white smoke was released and solution become clear, after that $20-30 \mathrm{ml}$ distilled water added to it and filtered and volume was made up to $100 \mathrm{ml}$. Then reading was taken by using atomic absorption (Spectra A).

\section{Determination of amylose content}

Amylose content was determined by Sompong (2011) method with some modification. Wheat flour $(0.02 \mathrm{~g})$ was taken into a volumetric flask. Then $0.2 \mathrm{ml}$ of ethanol $(95 \%)$ was added. After that $1.8 \mathrm{ml}$ of $1 \mathrm{~N} \mathrm{NaOH}$ was added and made $20 \mathrm{ml}$ total volume by adding distilled water. It was kept $20 \mathrm{~min}$ at room temperature and boiled for $10 \mathrm{~min}$ at $45^{\circ} \mathrm{C}$. It was filtered using Whatman filter paper (540). Then $1 \mathrm{ml}$ filtrate was transferred to a $50 \mathrm{ml}$ tube and $0.2 \mathrm{ml}$ of $1 \mathrm{M}$ acetic acid and $0.4 \mathrm{ml}$ Lugol's solution were added and made total volume $20 \mathrm{ml}$ by adding distilled water. The mixture was mixed and kept for $20 \mathrm{~min}$ at room temperature. Then the absorbance was taken at $620 \mathrm{~nm}$. The amylose content was determined using potato amylose standard curve and was expressed as $(\mathrm{mg} / \mathrm{ml})$.

Amylose was calculated by following formula

$$
\% \text { Amylose }=X(\mathrm{mg} / \mathrm{ml}) \times \frac{\text { total volume made up }}{\text { weight of powder }(\mathrm{mg})} \times 100
$$




\section{Determination of starch}

The starch content was determined according to the method reported by (Asaduzzaman et al., 2013) with some modification. Wheat flour $(5 \mathrm{~g})$ was taken in a beaker and 30 $\mathrm{ml}$ of water was added. It was transferred to the water bath and heated at $60^{\circ} \mathrm{C}$ for $25 \mathrm{~min}$. Then $100 \mathrm{ml}$ of $95 \%$ ethanol was added to it and stirred by magnetic stirrer for $15 \mathrm{~min}$. It was filtered through Whatman filter paper no.2. The residue was soaked in $50 \%$ ethanol solution for $1 \mathrm{hr}$. After that, the residue was washed on the filter paper with the $50 \%$ ethanol solution for $4 \mathrm{hr}$. The residue was collected in a round bottom flask and $100 \mathrm{ml}$ of water and $20 \mathrm{ml}$ of $37 \% \mathrm{HCl}$ added to it. The flask was attached with the condenser and heated for $2.5 \mathrm{hr}$. Then it was allowed to cool and neutralized by adding $\mathrm{NaOH}$ solution (40\%). After that $10 \mathrm{ml}$ of Fehling solution was taken in to a conical flask and titrated against neutralized sample solution. When copper sulfate like color was observed, then 3 drops of methylene blue indicator was added and continued titration. The end point was indicated by brick- red color.

The starch content was calculated by following formula

$$
\% \text { reducing sugar }=\frac{\text { factor for Fehling's solution } \mathrm{x} \text { dilution }}{\text { titre } \mathrm{x} \text { weight of powder }} \times 100
$$

$\%$ starch $=$ Reducing sugar $\times 0.9$

\section{Functional properties}

\section{Determination of water absorption index (WAI)}

The WAI content was determined according to the method reported by (Asaduzzaman et al., 2013) with some modification. Dried flour $(0.83 \mathrm{~g})$ was suspended with $10 \mathrm{ml}$ of water into a $30 \mathrm{ml}$ tared centrifuge tube. The mixture was centrifuged for $30 \mathrm{~min}$ at $4000 \mathrm{rpm}$ and the supernatant was poured carefully into a tared dish. The residue was weighed.

Water absorption index was determined by following formula:

$$
\mathrm{WAI}(\mathrm{g} / \mathrm{g})=\frac{\mathrm{W}_{1}-\mathrm{w}_{2}}{\mathrm{se}} \times 100
$$

Here,

$\mathrm{w}_{1}=$ weight of tube with residue $\mathrm{w}_{2}=$ weight of the tube

$\mathrm{w}=$ weight of sample

Determination of water solubility index (WSI)

The WAI content was determined according to the method reported by Asaduzzaman et al., (2013) with some modification. Dried flour $(0.83 \mathrm{~g})$ was suspended with $10 \mathrm{ml}$ of water into a $30 \mathrm{ml}$ tared centrifuge tube. The mixture was centrifuged for $30 \mathrm{~min}$ at $4000 \mathrm{rpm}$ and the supernatant was poured carefully into a tared dish. The supernatant was dried at $70^{\circ} \mathrm{C}$ until a constant weight was obtained. Then it was cooled and weighed.

Water solubility index was calculated by following formula:

Water Solubility Index $(\%)=\frac{W_{1}-w_{2}}{w} \times 100$

Here,

$\mathrm{w}_{1}=$ weight of dish and dried liquid

$\mathrm{w}_{2}=$ weight of dish

$\mathrm{w}=$ weight of dried sample

\section{Statistical analysis}

All measurements were carried out in triplicate for each of the sample except mineral (two times). Results are expressed as mean values standard deviation. Data were statistically analyzed (MSTAT-C windows version 2.10) Mean comparisons were performed using Duncan's multiple range tests for significant effect at $\mathrm{P}<0.05$.

\section{Result and discussion}

\section{Proximate analysis}

Proximate composition of different wheat flour are shown in Table-I. The moisture content of different brand wheat flour varied between $9.90 \%$ to $12.48 \%$. Our results were also closely related to some previous studies carried out by Syeda Afifa et al., (2012) who found that the moisture content in wheat flour in the ranged of $9.11 \%$ to $9.79 \%$. The highest value of moisture content $(12.48 \%)$ was found in Teer and lowest value $(9.90 \%)$ was found in Romoni. The difference of moisture contents in various brands wheat flour was due to genetic makeup of wheat varieties and it largely influenced by the agronomic and climatic conditions (Masood, 2004). The crude protein content of different brand wheat flour varied 
Table I. Proximate composition of the different brand wheat flour

\begin{tabular}{lllllll}
\hline Brand & Moisture \% & Crude Protein \% & Gluten \% & Fat \% & Ash \% & Fiber \% \\
\hline ACI & $12.04 \pm 0.19^{\mathrm{b}}$ & $12.47 \pm 2.15^{\mathrm{a}}$ & $13.232 \pm 2.16^{\mathrm{a}}$ & $0.893 \pm 0.09^{\mathrm{d}}$ & $0.387 \pm 0.07^{\mathrm{b}}$ & $0.04 \pm 0.02^{\mathrm{c}}$ \\
Teer & $12.48 \pm 0.15^{\mathrm{b}}$ & $10.63 \pm 0^{\mathrm{b}}$ & $14.90 \pm 1.16^{\mathrm{a}}$ & $1.067 \pm 0.11^{\mathrm{bcd}}$ & $0.387 \pm 0.07^{\mathrm{ab}}$ & $0.04 \pm 0.00^{\mathrm{c}}$ \\
Rabea & $11.48 \pm 0.05^{\mathrm{c}}$ & $08.67 \pm 0.08^{\mathrm{c}}$ & $14.47 \pm 1.76^{\mathrm{a}}$ & $0.913 \pm 0.10^{\mathrm{cd}}$ & $0.707 \pm 0.26^{\mathrm{c}}$ & $0.20 \pm 0.14^{\mathrm{ab}}$ \\
Romoni & $09.90 \pm 0.15^{\mathrm{e}}$ & $09.98 \pm 0.44^{\mathrm{bc}}$ & $15.34 \pm 1.48^{\mathrm{a}}$ & $1.387 \pm 0.04^{\mathrm{a}}$ & $0.513 \pm 0.10^{\mathrm{b}}$ & $0.26 \pm 0.08^{\mathrm{a}}$ \\
Utsab $^{\mathrm{b}}$ & $11.40 \pm 0.35^{\mathrm{c}}$ & $10.60 \pm 0.08^{\mathrm{b}}$ & $14.69 \pm 2.04^{\mathrm{a}}$ & $1.107 \pm 0.11^{\mathrm{bc}}$ & $0.513 \pm 0.07^{\mathrm{a}}$ & $0.11 \pm 0.07^{\mathrm{bc}}$ \\
Loose $^{*}$ & $10.70 \pm 0.43^{\mathrm{d}}$ & $09.72 \pm 0.08^{\mathrm{bc}}$ & $11.97 \pm 1.70^{\mathrm{a}}$ & $1.183 \pm 0.15^{\mathrm{b}}$ & $0.507 \pm 0.05^{\mathrm{a}}$ & $0.07 \pm 0.01^{\mathrm{c}}$ \\
BSTI $^{*}$ & 13 (max.) & N/A & $10(\max )$ & N/A & 0.7 & N/A \\
FCT $^{*}$ & 12.2 & 10.6 & N/A & 1.6 & 0.8 & N/A \\
\hline
\end{tabular}

Mean \pm SD (Three determinations)

Mean followed by different superscript in each column are significantly different $(\mathrm{P}<0.05)$.

* indicated open non - pack market flour

BSTI -Bangladesh Standard and Testing Institution

FCT - Food Composition Table for Bangladesh

N/A -Not Available

Table II. Mineral contents of the different brand wheat flour

\begin{tabular}{lllll}
\hline \multirow{2}{*}{$\begin{array}{l}\text { Wheat flour } \\
\text { brand }\end{array}$} & \multicolumn{3}{c}{ Mineral (mg/100g) } \\
\cline { 2 - 5 } & $\mathrm{Na}$ & $\mathrm{K}$ & $\mathrm{Ca}$ & $\mathrm{Mg}$ \\
\hline ACI & $131.04 \pm 26.07^{\mathrm{a}}$ & $140.75 \pm 5.52^{\mathrm{ab}}$ & $20.03 \pm 0.00^{\mathrm{a}}$ & $30.37 \pm 1.71^{\mathrm{ab}}$ \\
Teer & $54.02 \pm 11.38^{\mathrm{a}}$ & $125.11 \pm 5.52^{\mathrm{bc}}$ & $8.01 \pm 0.00^{\mathrm{a}}$ & $35.84 \pm 2.58^{\mathrm{a}}$ \\
Rabea & $45.62 \pm 15.76^{\mathrm{a}}$ & $154.43 \pm 2.76^{\mathrm{ab}}$ & $5.00 \pm 1.42^{\mathrm{a}}$ & $23.08 \pm 8.59^{\mathrm{ab}}$ \\
Romoni & $40.23 \pm 34.13^{\mathrm{a}}$ & $172.03 \pm 38.70^{\mathrm{a}}$ & $8.01 \pm 0.00^{\mathrm{a}}$ & $35.24 \pm 3.43^{\mathrm{ab}}$ \\
Utsab & $101.14 \pm 91.01^{\mathrm{a}}$ & $101.65 \pm 33.17^{\mathrm{c}}$ & $14.02 \pm 11.33^{\mathrm{a}}$ & $21.87 \pm 12.03 \mathrm{~b}$ \\
Loose & $81.61 \pm 8.13^{\mathrm{a}}$ & $140.75 \pm 16.58^{\mathrm{ab}}$ & $14.02 \pm 5.67^{\mathrm{a}}$ & $28.55 \pm 2.58 \mathrm{ab}^{\mathrm{ab}}$ \\
BSTI & $\mathrm{N} / \mathrm{A}$ & $\mathrm{N} / \mathrm{A}$ & $\mathrm{N} / \mathrm{A}$ & $\mathrm{N} / \mathrm{A}$ \\
FCT & 9.83 & 210.2 & 12.8 & 57.8 \\
\hline
\end{tabular}

Mean \pm SD (Three determinations)

Mean followed by different superscript in each column are significantly different $(\mathrm{P}<0.05)$.

* indicated open non - pack market flour

BSTI - Bangladesh Standard and Testing Institution

FCT -Food Composition Ta ble for Bangladesh

N/A - Not Available 
between $8.67 \%-12.47 \%$. These values were supported to the work of Ahmad et al. (2005) who studied that wheat flour contains $10.32 \%$ to $11.58 \%$ proteins. The highest value of crude protein present in ACI brand $(12.47 \%)$ the lowest amount of crude protein found in Rabea brand (8.67\%). This variation it may be due to genetic makeup and on external factors associated with the crop (Shahidur et al., 2011). The gluten content in wheat flour was varied between ranged $11.97 \%-15.34 \%$. The highest gluten found in Romoni brand wheat flour (15.34\%) and lowest (11.97\%) in Loose wheat flour. This result was similar with the work of Syeda Afifa et al., (2012) who observed gluten content in wheat flour ranged from $9.88 \%$ to $26.21 \%$. The difference of gluten level is due to the difference in the genetic makeup of the wheat varieties, and climate conditions, growth conditions (Randhawa et al., 2002).. The lowest fat percentage in ACI these results were higher than that the work of Ajani et al. (2012) who recorded fat content in wheat flour was $(0.42 \%)$ and highest fat found in Romoni (1.387\%) which is supported the study of Baljeet et al., (2010) who found fat content in wheat flour was $(1.81 \%)$. The variation of the fat value in different brand wheat flour it may be due to the presence of lipase or lipase activity which is responsible for the hydrolysis of lipids in dormant wheat during storage (Rose et al., 2006). The ash content in different brand wheat flour ranged from $0.387 \%$ and $0.707 \%$. This result was similar to work of Ahmad et al. (2005) who reported ash content in wheat flour $0.52-0.68 \%$. The highest ash value was obtained in Rabea brand $(0.707 \%)$ while lowest value $(0.387 \%)$ found in ACI and Teer brand. The high level of ash are generally associated with the addition of bran in the wheat (Ali et al.,2009). The fiber content of all the brand wheat flour was varied between $0.04 \%$ to $0.26 \%$. The highest $(0.26 \%)$ fiber content was found in Romoni brand wheat flour whereas lowest in ACI and Teer were $(0.04 \%)$. This value was similar the findings of Ade-Omowaye et al. (2008) who reported that the fiber content of wheat flour was $0.30 \%$. Those values also were consistent with Olaoye et al. (2006) who observed that the fiber in bread wheat flour $(0.03 \%)$. The fiber content of wheat flour was lower than those obtained by Horsfall et al. (2007) who observed that the fiber content in wheat flour was $0.82 \%$. This variation of fiber could be due depend on extraction rate as well as genotype or environment (Hossain, et al., 2013). Minerals contents of wheat flour were shown in (Table-II). Moisture content, crude protein, fat and ash content did not exceed maximum level except gluten content as compared to Bangladesh Standard Testing Institution (BSTI) and Food Composition Table for Bangladesh (FCT). Gluten content was higher than BSTI value. It might be due to depend on extraction rate of gluten.
The mineral content of different brand wheat flour varied between $\mathrm{Na}$ (40.23-131.04 mg/100g), K (101.65-172.03 $\mathrm{mg} / 100 \mathrm{~g}), \mathrm{Ca}(5.00-20.03 \mathrm{mg} / 100 \mathrm{~g})$ and $\mathrm{Mg}(21.87-35.84$ $\mathrm{mg} / 100 \mathrm{~g})$. The highest $\mathrm{Na}$ content found in ACI (131.04 $\mathrm{mg} / 100 \mathrm{~g}$ ) and the lowest in Romoni $(40.23 \mathrm{mg} / 100 \mathrm{~g})$. These values was lower than jack bean flour $(198 \mathrm{mg} / 100 \mathrm{~g})$ but higher than cowpea flour $(120 \mathrm{mg} / 100 \mathrm{~g})$. The highest $\mathrm{K}$ content obtained from Romoni (172.03 mg/100g) ) and lowest Utsab (101.65 mg/100g). This value was higher than that found by Esmat et al. (2010) who reported K content of wheat flour were $(102.50 \mathrm{mg} / 100 \mathrm{~g})$. The maximum amount of $\mathrm{Ca}$ was observed from ACI $(20.03 \mathrm{mg} / 100 \mathrm{~g})$ and lowest in Rabea $(5.00 \mathrm{mg} / 100 \mathrm{~g})$. These values were close to the Ahmed et al. (2013) who reported that the Ca content of wheat flour was 23 $\mathrm{mg} / 100 \mathrm{~g}$. On the other hand the highest $\mathrm{Mg}$ was obtained from Teer (35.84 mg/100g) and lowest in Utsab $(21.87 \mathrm{mg} / 100 \mathrm{~g})$. These value was lower than that the work of Esmat et al. (2010) who reported the wheat flour contain (89.67 mg/100g) Mg and the value also lower than Jackpea $(135 \mathrm{mg} / 100 \mathrm{~g})$, Pigeon pea $(155 \mathrm{mg} / 100 \mathrm{~g})$ and Cowpea (95mg/100g) (Arawande et al., 2010). The variation of mineral content in different wheat flour it may be due to application of different processing method as well as the separation of germ and bran during milling (Wang et al., 2008). Contents of $\mathrm{K}$ and $\mathrm{Mg}$ were lower whereas Na contents were higher than the Food Composition Table for Bangladesh (FCT) however, Ca contents were consistent with Food Composition Table for Bangladesh (FTC). It may be due to the difference in the genetic makeup of the wheat varieties and climate conditions as well as growth conditions.

\section{Physiochemical analysis}

\section{Amylose and starch}

Starch and Amylose content are summarized in Table-III. The amount of starch in different brand wheat flour varied between $79.84 \%$ to $72.38 \%$. ACI brands had highest (79.84\%) as compared to other brand. This result was supported the studied of Kumar et al. (2011) who reported the starch content in wheat flour was $76.2 \%$ and Zuzana et al. (2009) who observed the amount of starch in wheat grain ranged $60 \%$ to $75 \%$. On the other hand, the highest amylose content in Teer $(28.45 \%)$ and lowest amylose content in Romoni brand (12.00\%). The similar report was shown by Konik-Rose et al. (2007) who found that normal wheat starch typically contains $20-30 \%$ amylose. The variation in amylose and starch content in different brand wheat flour may be due to the application of fertilizer and growing conditions and time and location of growing region as well as right genetic make-up also (Edwards, 2007). 
Table III. Physiochemical properties of different brand wheat flour

\begin{tabular}{lllllllll}
\hline Parameter & \multicolumn{7}{c}{ Wheat flour brand } & \\
\cline { 2 - 6 } & ACI & Teer & Rabea & Romoni & Utsab & Loose & BSTI & FCT \\
\hline Starch (\%) & $79.85 \pm 1.60^{\mathrm{a}}$ & $74.94 \pm 1.82^{\mathrm{bcd}}$ & $74.03 \pm 0.68^{\mathrm{bcd}}$ & $76.94 \pm 2.68^{\mathrm{ab}}$ & $73.29 \pm 1.54^{\mathrm{cd}}$ & $72.38 \pm 0.599^{\mathrm{d}}$ & N/A & N/A \\
Amylose (\%) & $22.16 \pm 7.4^{\mathrm{ab}}$ & $28.45 \pm 4.62^{\mathrm{a}}$ & $24.73 \pm 3.14^{\mathrm{ab}}$ & $12.00 \pm 2.6^{\mathrm{c}}$ & $19.08 \pm 3.65^{\mathrm{bc}}$ & $22.68 \pm 5.06^{\mathrm{ab}}$ & N/A & N/A \\
\hline
\end{tabular}

Mean \pm SD (Three determinations)

Mean followed by different superscript in each row are significantly different

$(\mathrm{P}<0.05)$. * indicated open non -pack market flour

BSTI -Bangladesh Standard and Testing Institution

FCT -Food Composition Table for Bangladesh

N/A - Not Available

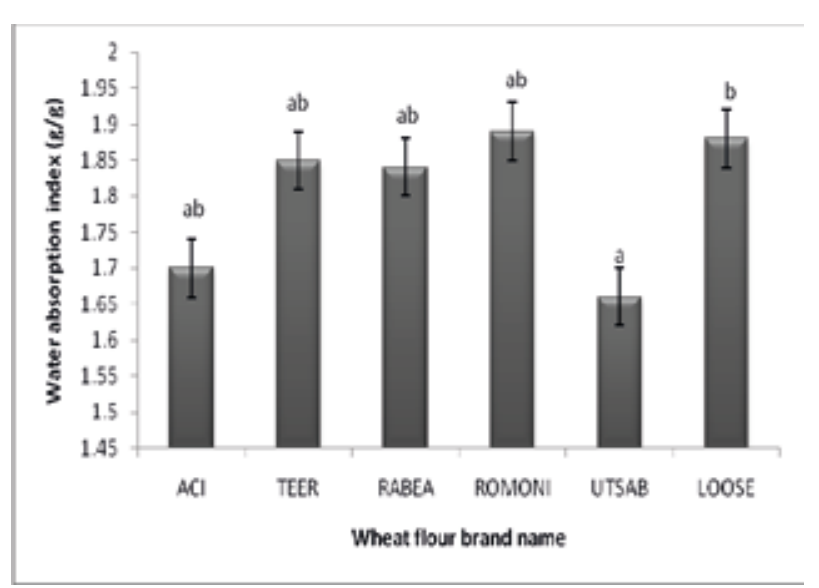

Fig. 1. Water absorption index among six brand wheat flour

\section{Functional properties}

Fig. 1. and Fig. 2. show the functional properties of different brand wheat flours. The water absorption index (WAI) in different brand wheat flour varied between $1.697 \mathrm{~g} / \mathrm{g}$ to $1.897 \mathrm{~g} / \mathrm{g}$. The highest value had found in Romoni while the lowest value of water absorption index in ACI. These might be attributed to higher fibre contents and also loss of starch

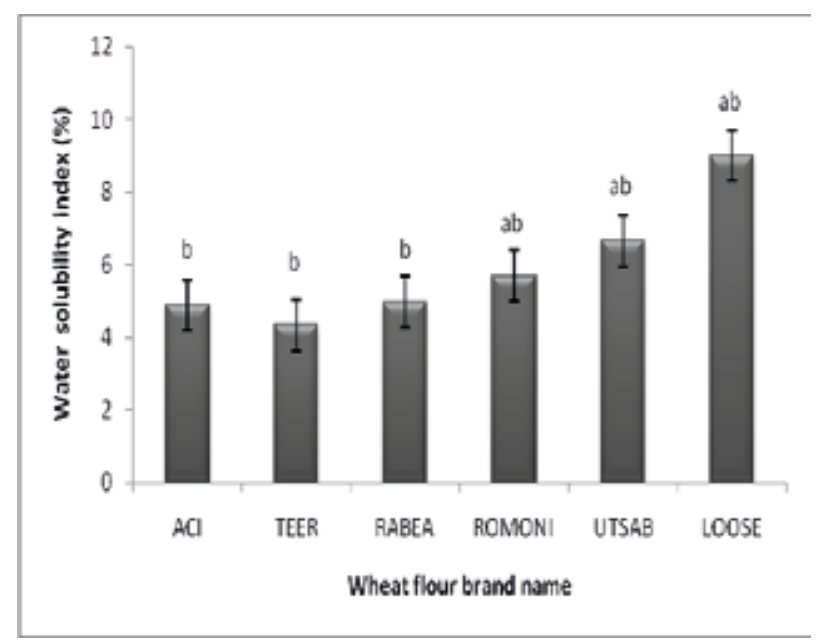

Fig. 2. Water solubility index among six brand wheat flour

crystalline structure (Asaduzzaman et al., 2013). The water soluble index in different brand wheat flour ranged between 4.33-8.99\%. The highest value obtained from Loose brand and lowest value from Teer. Water solubility index can depend on the semi crystalline structure and disruption of starch granule and water molecules are bonded to the free hydroxyl groups of amylose and amylopectin by hydrogen bonds (Eliasson and Gudmundsson, 1996). 


\section{Conclusion}

Wheat is one of the most important staple food crop and widely used in the world. This study investigated on various commercial packed flour and analyzed their quality or specification to help better selection of commercial packed wheat flour for the people. This study recommended that all commercial flours could be used as well as loose flours might be also used as various value added products.

\section{Acknowledgement}

This study was supported by University Grant Commission of Bangladesh through Institute of Research and Training, Hajee Mohammad Danesh Science and Technology University, Dinajpur for financial support.

\section{References}

Ade-Omowaye BIO, Akinwande BA, Bolarinwa IF and Adebiyi AO (2008), Evaluation of tigernut (Cyperusesculentus) -wheat composite flour and bread, Afri. J. Food Sci. 2: 087-091.

Ahmad I, Ahmad N, Kausar T and Ashraf M (2005), Effect of maltogenic amylase on the shelf life of bread, Pak. J. Food Sci. 15: 15-19.

Ahmed MSH, Mohie MK, Nefisa AH and Abo El-Nor SAH (2013), Effect of Wheat Flour Supplemented with Barely and/or Corn Flour on Barley Bread Quality, Pol. J. Food Nutr. Sci. 63: 11-18.

AOAC (2000), Association of Official Analytical Chemistry, Washington DC, pp-12-14.

Arawande JO and Borokini FB (2010), Comparative Study on Chemical Composition and Functional Properties of Three Nigerian Legumes (Jack Beans, Pigeon Pea and Cowpea, J. E. Trends. Engg. Appl. Sci. 1: 89-95.

Asaduzzaman M, Haque ME, Rahman J, Hasan SMK, Ali MA, Akter MS and Ahmed M (2013), Comparisons of physiochemical, total phenol, flavonoid content and functional properties in six cultivars of aromatic rice in Bangladesh, Afri. J. Food Sci. 7: 198-203.

Ajani AO, Oshundahunsi OF, Akinoso R, Arowora KA, Abiodun AA and Pessu PO (2012), Proximate Composition and Sensory Qualities of Snacks Produced from Breadfruit Flour, Global J. Sci.Fronier Res.Bio. Sci. 12: 1-8.
Ali A, Peter P and Frans SJM (2009), Thephysico-chemical and microbiological properties of wheat flour in Thrace,Tr J. Agri. 33: 445-454.

Ayesha S, Abid N and Anjum FM (2002), Chemical Composition of Three Wheat (Triticumaestivum L.) Varieties as Affected by NPK Doses, Int. J. Agri. and Bio. 4: 537-539.

Baljeet SY, Ritika BY and Roshan LY (2010), Studies on functional properties and incorporation of buckwheat flour for biscuit making, Int. Food Res. J. 17: 1067-1076.

BBS (2012), Statistical Year Book of Bangladesh, Bangladesh Bureau of Statistics, Planning Division, Ministry of Planning, Government of the People's Republic of Bangladesh.

Chowdhury K, Khan S, Karim R, Obaid M and Hasan GMMA (2012), Quality and Shelf-Life Evaluation of Packaged Biscuits Marketed in Bangladesh, Bangladesh J. Sci. Ind. Res. 47: 29-42.

Duska C, Damir K, Dubravka T, Biserka P and Jelena D (2001), Gluten as a Standard of Wheat Flour Quality, Food Tech. Biotechnol. 39: 353-361.

Edwards WP (2007), The Science of Bakery Products, Published by The Royal Society of Chemistry, Thomas Graham House, Science Park, Milton Road, Cambridge, UK, p-60.

Eliasson AC and Gudmundsson M (1996), Starch: Physicochemical and functional aspects, in: Carbohydrates in Food.2nd edition. (Marcel Dekker, Inc., New York 1996), pp. 431-503.

Esmat A, Abou A, Helmy IMF and Bareh GF (2010), Nutritional Evaluation and Functional Properties of $\begin{array}{ll}\text { Chickpea (Cicerarietinum L.)Flour and the } & \text { ar. }\end{array}$ Improvement of Spaghetti, J. Amer. Sci. 6:1061.

Food and Agricultural Organization (FAO), Food Outlook Global Market analysis November (2012), ISSN 0251-1959.

Perten H , Bondesson K and Mjorndal V (1992), Cereal Foods World, 37: 655-660.

Hasan MN, Miah MAM, Islam MS, Alam QM and Hossain MI (2008), Change and instability in area and production of wheat and maize in Bangladesh, Bangladesh J. Agril. Res. 33: 409-417. 
Horsfall D, Mepba LE and Nwaojigwa SU (2007), Chemical composition, functional and baking properties of wheat-plantain composite flours, Afri. J. Food Agri. Nutr. Dev. 7: 1684-5374.

Hossain K, Ulven C, Glover K, Ghavami F, Simsek S, Alamri MS, Kumar A and Mergoum M (2013), Interdependence of cultivar and environment on fiber composition in wheat bran, Aus. J. Crop Sci. 7: 525-531.

Hoseney RC (1994), Principles of Cereal Science and Technology. $2^{\text {nd }}$ ed. Am. Assoc. of a Cereal Chem. Inc., St. Paul, Minnesota, USA.

Hruskova M and Famera O (2003), Prediction of wheat and flour Zeleny sedimentation value using NIR technique, Czech J. Food Sci. 21: 91-96.

Husejin K, Mirsad S, Amra O, Midhat J, Nihada A and Indira $\breve{S}$ (2009), The Importance of Determination of some Physical - Chemical Properties of Wheat and Flour, Agri. Conspectus Scientifics, 74: 197-200).

Konik-Rose CH, Thistleton J, Chanvrier H, Tan I, Halley P, Gidley M, Kosar-Hashemi B, Wang H, Larroque O, Ikea J, McMaugh S, Regina A, Rahman S, Morell M and Li Z (2007), Theor. Appl. Genet. 115: 1053-1065

Kumar P, Yadava RK, Gollen B, Kumar S, Verma RK and Yadav S (2011), Nutritional Contents and Medicinal Properties of Wheat, L. Sci. M. Res. 22: 1-7.

Masood SB, Muhammad N, Saeed A and Kamran S (2004), Effect of Moisture and Packaging on the Shelf Life of Wheat Flour, Int. J. Food Safety 4: 1-6.

Olaoye OA, Onilude AA and Idowu OA (2006), Quality characteristics of bread produced from composite flours of wheat, plantain and soybeans, Afri. J. Biotechnol. 5: 1102-1106.

Randhawa MA, Anjum FM and Butt MS (2002), Physico-chemical and milling properties of new spring wheat's grown in Punjab and Sind for the production of pizza, Int. J. Agri. Bio. 4: 482-484.

Rose DJ and Pike OA (2006), A simple method to measure lipase activity in wheat and wheat bran as an estimation of storage quality, J. Amer. Oil Chem. Soc. 83: 415-419.

Said Wahab (2010), Effect of calcium fortification on the overall quality of whole wheat flour leavened and unleavened bread. Ph.D. Thesis, pp-12-14 Zhe Jiang University, China.

Rahman MS and Kader MA (2011), Comparison of nutritional and Physicochemical Properties of Bangladeshi wheat verities, W. Appl. Sci. J. 12: 178-181.

Sompong R, Ehn S, Martin L and Berghofer E (2011), Physicochemical and antioxidant properties of red and black rice varieties from Thailand, China and Sri Lanka, Food Chem. 124: 132-140.

Syeda A, Batool N, Rauf, Tahir SS and Razia K (2012), Microbial and Physico-chemical contamination in the wheat flour of the twin cities of Pakistan, Int. J. Food Safety 14: 75-82.

Tama's C, Kisgyo'rgy BN, Rakszegi M, Wilkinson MD, Yang M, La'ng L, Tama's and Bed Z (2009), Transgenic approach to improve wheat (Triticum aestivam L.) nutritional quality, Plant cell Rep. 28: 1085-1094.

Taneya MLJ, Biswas MMH and Shams-Ud-Din M (2014), The studies on the preparation of instant noodles from wheat flour supplementing with sweet potato flour, $J$. Bangladesh Agril. Univ. 12: 135-142.

Wang N, Hatcher DW and Gawalko EJ (2008), Effect of variety and processing on nutrients and certain anti-nutrients in field peas (Pisum sativum), Food Chem. 111: 132-138.

Wrigley C (2004), Cereals - Overview, Encyclopedia of Grain Science, pp-187-201;

Zuzana S̆, Edita G and Ernest $\breve{S}$ (2009), Chemical composition and nutritional quality of wheat grain, Acta Chimica Slovaca, 2:115 - 138 .

Received: 06 January 2015; Revised: 10 June 2015; Accepted: 30 June 2015. 